\title{
Evaluation of the Use of Synroc to Solidify the Cesium and Strontium Separations Product from Advanced Aqueous Reprocessing of Spent Nuclear Fuel
}

\author{
Julia Tripp \\ Vince Maio \\ March 2006
}

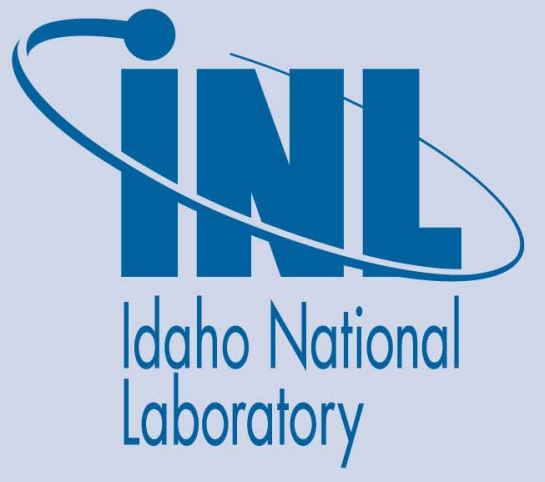

The INL is a U.S. Department of Energy National Laboratory operated by Battelle Energy Alliance 
INL/EXT-06-01377

\title{
Evaluation of the Use of Synroc to Solidify the Cesium and Strontium Separations Product from Advanced Aqueous Reprocessing of Spent Nuclear Fuel
}

\author{
Julia Tripp \\ Vince Maio
}

March 2006

Idaho National Laboratory

Idaho Falls, Idaho 83415

Prepared for the

U.S. Department of Energy

Office of Nuclear Energy

Under DOE Idaho Operations Office

Contract DE-AC07-05ID14517 


\section{DISCLAIMER}

This information was prepared as an account of work sponsored by an agency of the United States Government. Neither the United States Government nor any agency thereof, nor any of their employees, makes any warranty, express or implied, or assumes any legal liability or responsibility for the accuracy, completeness, or usefulness of any information, apparatus, product, or process disclosed, or represents that its use would not infringe privately owned rights. References herein to any specific commercial product, process, or service by trade name, trademark, manufacturer, or otherwise, does not necessarily constitute or imply its endorsement, recommendation, or favoring by the United States Government or any agency thereof. The views and opinions of authors expressed herein do not necessarily state or reflect those of the United States Government or any agency thereof. 


\section{CONTENTS}

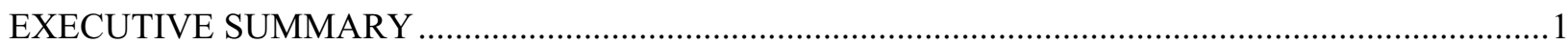

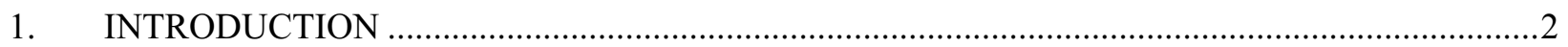

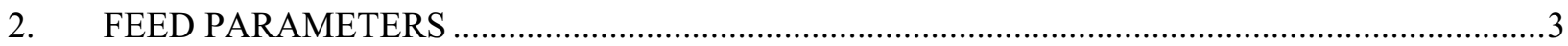

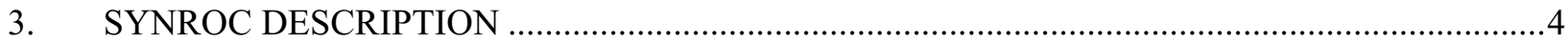

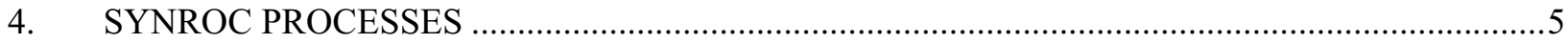

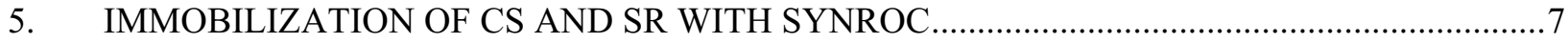

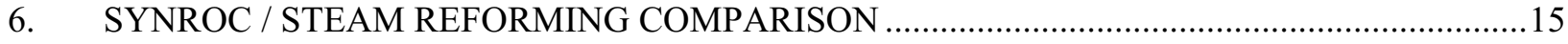

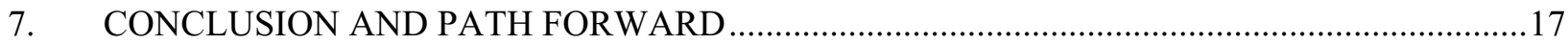

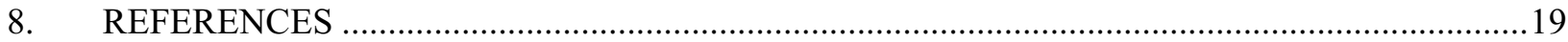




\section{ACRONYMS}

AFCI Advanced Fuel Cycle Initiative

ANSTO Australian Nuclear Science and Technology Organisation

CCD chlorinated cobalt dicarbollide

CCIM Cold Crucible Induction Melter

CEA Commissariat à l'Energie Atomique

DTPA diethylenetriaminepentaacetic acid

DOE Department of Energy

FPEX Fission Product Extraction

FY Fiscal Year

HIC High Integrity Container

HIP Hot Isostatic Press

HLW High Level Waste

INL Idaho National Laboratory

LANL Los Alamos National Laboratory

LLW low level waste

MAC methylamine carbonate

MCC Materials Characterization Center

NZP sodium zirconium phosphate

PCT Performance Consistency Test

PEG polyethylene glycol

PNNL Pacific Northwest National Laboratory

UREX+ Uranium Extraction + 


\section{Evaluation of the Use of Synroc to Solidify the Cesium and Strontium Separations Product from Advanced Aqueous Reprocessing of Spent Nuclear Fuel}

\section{EXECUTIVE SUMMARY}

To reduce the short-term decay heat load in the potential high-level radioactive liquid waste (HLW) to be generated by the proposed future nuclear fuel aqueous-based reprocessing schemes, research under the Department of Energy's (DOE's) Advanced Fuel Cycle Initiative (AFCI) is being conducted on the development of solvent extraction processes that specifically separate the predominant fission products of cesium (Cs) and strontium (Sr). To ensure reliable, safe, cost effective, and stakeholder acceptable waste forms for the nuclear fuel cycle of the future, this $\mathrm{Cs} / \mathrm{Sr}$ strip solution will require immobilization for managed storage or disposal. To that end, the Idaho National Laboratory (INL) was tasked to complete a literature evaluation of the Synroc process, including determining the potential for its application in immobilizing this $\mathrm{Cs} / \mathrm{Sr}$ strip product.

Synroc is an advanced crystalline ceramic comprised of geochemically stable natural titanate minerals, which have immobilized uranium and thorium in the natural environment. These natural analogs can incorporate into their crystal structures nearly all of the elements present in HLW, thus immobilizing them. Synroc can take various forms depending on its specific use and can be tailored to immobilize particular components in the HLW. The main titanate minerals in Synroc-C are hollandite $\left(\mathrm{BaAl}_{2} \mathrm{Ti}_{6} \mathrm{O}_{16}\right)$, zirconolite $\left(\mathrm{CaZrTi}_{2} \mathrm{O}_{7}\right)$ and perovskite $\left(\mathrm{CaTiO}_{3}\right)$. Zirconolite and perovskite are the major immobilization hosts for long-lived actinides such as plutonium $(\mathrm{Pu})$ and the rare earths, whereas perovskite is principally for Sr. Hollandite principally immobilizes $\mathrm{Cs}$, along with potassium $(\mathrm{K})$, rubidium $(\mathrm{Rb})$ and barium $(\mathrm{Ba})$.

A significant amount of research in several countries, with Australia being the most predominant, has been completed and documented on the use of Synroc for the immobilization of $\mathrm{Cs}$ and $\mathrm{Sr}$. This literature evaluation determined that Synroc is expected to provide a reliable and durable waste form for the $\mathrm{Cs} / \mathrm{Sr}$ strip product. In general, the Cs sequestering hollandite mineral phase is chemically durable with a leach resistance two orders of magnitude higher than for the currently established HLW form of borosilicate glass. The use of tailored, high-performance, alternative waste forms that include ceramics and glass-ceramics, coupled with alternative near-mature process technologies, such as hot-isostatic pressing, sintering and cold-crucible induction melting, offer significant performance improvements and efficiency savings for wastes difficult to incorporate into glass. Consequently, the use of Synroc as an alternative for the immobilization of the $\mathrm{Cs} / \mathrm{Sr}$ strip product must be further evaluated for future applications. 


\section{INTRODUCTION}

The Advanced Fuel Cycle Initiative (AFCI) is conducting research on aqueous separations processes for the nuclear fuel cycle. This research includes development of solvent extraction processes for the separation of cesium (Cs) and strontium ( $\mathrm{Sr}$ ) from spent nuclear fuel to reduce the short-term decay heat load of the high-level waste (HLW). The $\mathrm{Cs} / \mathrm{Sr}$ strip solution from candidate separation processes will require treatment and immobilization for managed storage and/or final disposal.

The thermal load on the repository is greatly reduced if the emplacement of $\mathrm{Cs} / \mathrm{Sr}$ waste is delayed until these relatively short-lived (half-lives of $\sim 30 \mathrm{yrs}$ ) materials decay. Separation of $\mathrm{Cs}$ and $\mathrm{Sr}$ along with plutonium and americium would allow a substantial increase in the repository loading, up to a factor of 40-50. The storage of $\mathrm{Cs}$ and $\mathrm{Sr}$ for the life cycle of the waste processing plant can be accomplished using existing casks and requiring a relatively small area (one to two football fields in size for the life of the plant). Safe interim storage will require a waste form that is stable, does not produce dangerous radiolysis products (e.g., buildup of potentially explosive gases like hydrogen), has a relatively high product density (to minimize storage volume), and has properties that enhance heat management (e.g., high thermal conductivity).

In fiscal year 2004, an Engineered Product Activity Team was formed from a subset of the members of the AFCI Separations Working Group.[1] This team identified the preferred storage forms and vehicles for the $\mathrm{Cs} / \mathrm{Sr}$ waste stream arising from the treatment of spent fuel. For the $\mathrm{Cs} / \mathrm{Sr}$ waste stream, this team reported that encapsulation in borosilicate glass, similar to that used for high level waste, may be considered a baseline against which other storage forms are judged. The four most promising alternative $\mathrm{Cs} / \mathrm{Sr}$ storage forms identified by this team included:

- Ion-exchange of the $\mathrm{Cs}$ and $\mathrm{Sr}$ in zeolites, which are then immobilized in a cement matrix (Portland, apatite, phosphate-bonded, or refractory)

- Immobilization using Sodium Zirconium Phosphate (NZP) that is possibly diluted with a cement matrix

- Use of a steam reformer to produce a stabilized $\mathrm{Cs} / \mathrm{Sr}$ mineralized granular product waste form (i.e., the Washington Group International storage form)

- Immobilization of Cs and Sr in an optimized Synroc crystalline assemblage

Research initiated by the Idaho National Laboratory (INL) in FY-05 is focusing on the development and testing of the steam reforming solidification process and ion exchange testing with the emphasis being on steam reforming. The FY-05 steam reforming testing successfully converted $\mathrm{Cs} / \mathrm{Sr}$ strip products to a solid form without volatilizing the Cs.[2] Results also indicate that with optimization of the steam reforming operating parameters $100 \%$ mineralization is possible. The limited ion exchange batch contact testing results indicated that the crystalline silicotitanate inorganic ion exchange sorbent has high selectivity for Cs removal from dilute nitric acid and slightly alkaline strip solutions and 
minimal selectivity for $\mathrm{Sr}$ removal from dilute nitric acid but good selectivity for $\mathrm{Sr}$ removal from a slightly alkaline strip solution.

In FY-06, INL work on the ion exchange was suspended but optimization of the steam reforming operating parameters is continuing.[3] The INL was also tasked to complete a literature evaluation of the Synroc process including determining the potential for its application to immobilization of the $\mathrm{Cs} / \mathrm{Sr}$ strip product. This report summarizes the Synroc evaluation.

\section{FEED PARAMETERS}

The baseline process for separation of $\mathrm{Cs}$ and $\mathrm{Sr}$ from dissolved spent light water reactor fuel, as part of the Uranium Extraction Plus (UREX+) process, is a solvent extraction process utilizing chlorinated cobalt dicarbollide and polyethylene glycol (CCD/PEG) in a phenyltrifluormethyl sulfone (FS-13) diluent. Cs and Sr are stripped from the CCD/PEG organic stream with an aqueous solution of guanidine carbonate and diethylenetriaminepentaacetic acid (DTPA) yielding a metal carbonate product solution. Alternative extraction processing methods are also under investigation. The first alternative is a variation of the baseline $\mathrm{CCD} / \mathrm{PEG}$ process but uses a methylamine carbonate (MAC)/DTPA solution to strip the organic extractant. This yields a product containing the metals and DTPA (with small amounts of MAC) and allows the MAC to be recovered and recycled. A second alternative is the Fission Product Extraction (FPEX) process which extracts the $\mathrm{Cs} / \mathrm{Sr}$ with a calixarene-crown ether extractant consisting of $4,4^{\prime},\left(5^{\prime}\right)$ Di-(t-butyldicyclo-hexano)-18-crown-6 (DtBuCH18C6), Calix[4]arene-bis-(tertoctylbenzo-crown-6) (BOBCalixC6), and 1-(2,2,3,3-tetrafluoropropoxy)-3-(4-secbutylphenoxy)-2-propanol (Cs-7SB modifier) in a branched aliphatic kerosene (Isopar ${ }^{\circledR}$ L). With this process, the organic extractant is stripped with dilute nitric acid.

The estimated compositions of the $\mathrm{Cs} / \mathrm{Sr}$ strip solutions/immobilization process feeds are summarized in Table 1.

Table 1. Estimated composition of $\mathrm{Cs} / \mathrm{Sr}$ strip product feed streams.

\begin{tabular}{|l|c|c|c|}
\hline \multicolumn{1}{|c|}{ Component } & $\begin{array}{c}\text { CCD/PEG } \\
\text { Feed 1 }\end{array}$ & $\begin{array}{c}\text { CCD/PEG Feed } \\
\mathbf{2}\end{array}$ & FPEX Feed 3 \\
\hline Guanidine carbonate (g/L) & 100 & --- & --- \\
\hline DTPA (g/L) & 20 & 60 & --- \\
\hline Methylamine carbonate $(\mathrm{M})$ & --- & 0.5 & --- \\
\hline Nitric acid $(\mathrm{M})$ & --- & --- & 0.04 \\
\hline Cesium $(\mathrm{g} / \mathrm{L})$ & 0.30 & 1.2 & 0.60 \\
\hline Strontium $(\mathrm{g} / \mathrm{L})$ & 0.10 & 0.4 & 0.20 \\
\hline Barium $(\mathrm{g} / \mathrm{L})$ & 0.28 & 1.12 & 0.56 \\
\hline Rubidium $(\mathrm{g} / \mathrm{L})$ & 0.05 & 0.20 & 0.10 \\
\hline
\end{tabular}




\section{SYNROC DESCRIPTION}

Synroc is a type of "synthetic rock", invented in 1978 by the late Professor Ted Ringwood of the Australian National University. It is an advanced ceramic comprised of geochemically stable natural titanate minerals, which have immobilized uranium and thorium in the natural environment. These natural analogs can incorporate nearly all of the elements present in HLW into their crystal structures thereby immobilizing them. Synroc can take various forms depending on its specific use and can be tailored to immobilize particular components in the HLW. Synroc-C was intended mainly for the immobilization of liquid HLW arising from the reprocessing of light water reactor fuel.

The main titanate minerals in Synroc-C are hollandite $\left(\mathrm{BaAl}_{2} \mathrm{Ti}_{6} \mathrm{O}_{16}\right)$, zirconolite $\left(\mathrm{CaZrTi}_{2} \mathrm{O}_{7}\right)$ and perovskite $\left(\mathrm{CaTiO}_{3}\right)$. Zirconolite and perovskite are the major hosts for long-lived actinides such as plutonium $(\mathrm{Pu})$ and the rare earths, though perovskite is principally for Sr. Hollandite principally immobilizes $\mathrm{Cs}$, along with potassium (K), rubidium $(\mathrm{Rb})$ and barium $(\mathrm{Ba})$. [4] The hollandite group of minerals has the general formula $\mathrm{A}_{\mathrm{x}} \mathrm{B}_{\mathrm{y}} \mathrm{C}_{8-\mathrm{y}} \mathrm{O}_{16}$. In the crystal structure of Synroc-type hollandite the $\mathrm{B}$ and $\mathrm{C}$ cations are surrounded by octahedral configurations of oxygen. Each of these $(B, C) \mathrm{O}_{6}$ octahedral share two edges to form paired chains running parallel to the c- axis. These chains are corner linked to neighboring paired chains to form a three-dimensional framework with tunnels running parallel to the c-axis. The large A cations are located in these tunnels. In Synroc-type hollandite, the A position is occupied by $\mathrm{Cs} / \mathrm{Rb}$ and $\mathrm{Ba}$, the $\mathrm{B}$ position by $\mathrm{Al}$ and $\mathrm{Ti}^{3+}$, and the $\mathrm{C}$ position by $\mathrm{Ti}^{4+} \cdot[5]$

To achieve maximum cost savings and optimum performance the Synroc waste forms are tailored to suit the particular characteristics of nuclear waste to be immobilized rather than adopting a single one-size fits all approach. The Australian Nuclear Science and Technology Organisation (ANSTO) has demonstrated that significant reductions in waste volume for the partitioning/conditioning strategy can be achieved through immobilization of the heat-generating radionuclides, i.e., Cs-137, Sr-90, and Cm-244 together with longlived Tc-99 in Synroc, while remaining waste is immobilized in glass. The combination of partitioned $\mathrm{Cs}$ and $\mathrm{Sr}$ with $\mathrm{Cu}-244$ ensures that the effects of alpha-decay processes on the waste form durability are minimized through self-annealing of alpha-decay damage due to the radiogenic decay heat.[4]

Cs host forms must be stable under $(\beta, \gamma)$-irradiation, chemically durable and must accommodate the changes in chemistry resulting from the Cs decay process to $\mathrm{Ba}$.[6] The use of $\mathrm{Ti}$ is important because, as $\mathrm{Cs}^{+}$undergoes $\beta$-decay forming $\mathrm{Ba}^{2+}$ a charge imbalance results. In order to compensate for this, $\mathrm{a} \mathrm{Ti}^{4+}$ cation in the lattice undergoes reduction to $\mathrm{Ti}^{3+}$ conserving the charge balance. $\mathrm{Cs}^{+}$can be immobilized in hollandites that contain $\mathrm{Al}^{3+}$ and $\mathrm{Mg}^{2+}$. In these systems, the $\mathrm{Al}^{3+}$ and $\mathrm{Mg}^{2+}$ are present to ensure charge balance is maintained during formation, preventing the premature formation of $\mathrm{Ti}^{3+}$. Such components are also used to modify the tunnel size allowing larger atoms to be accommodated.[7] 
The temperature of hollandite ceramics containing $5 \mathrm{wt} \%$ of $\mathrm{Cs}_{2} \mathrm{O}$ could reach $300^{\circ} \mathrm{C}$ at the beginning of the waste storage. The extent to which the radioactive cesium radiation will produce permanent damage, notably structural changes, is strongly dependent on dose rate and on the availability of thermal energy for self-healing recombination mechanisms. It is difficult to predict the behavior of hollandite because of the kinetic factor and the simultaneous irradiation and annealing.[8]

The principal advantage of the Synroc C ceramic is that the waste ions were incorporated (HLW loading could be varied between 0 and $35 \mathrm{wt} \%$ ) in durable titanate mineral phases, which are considerably more insoluble in water (two orders of magnitude) than the silicates and phosphates in the supercalcine ceramics.

"Supercalcine" ceramics based on crystalline silicates, phosphates and molybdates were formed by sintering in air at $\sim 1100^{\circ} \mathrm{C}$ and had very high fission product loadings.

Typical phases for supercalcine were pollucite $\mathrm{CsAlSi}_{2} \mathrm{O}_{6}$; powellite $\mathrm{CaMoO}_{4}$, and rare earth apatites and phosphates.[9]

In 1981, there was a selection process in the US for candidate waste forms for the HLW produced form nuclear weapons based reprocessing and stored at the Savannah River Site. Synroc came second behind borosilicate glass in this assessment because, although the leach resistance of Synroc $C$ hollandite is two orders of magnitude higher than for the current borosilicate glass, the engineering development was lacking. Therefore, the Australian Government financed the construction of a Synroc Demonstration Plant at ANSTO in the mid-1980s. This plant can produce inactive Synroc monoliths at the $50 \mathrm{~kg}$ scale with a throughput of $10 \mathrm{~kg} / \mathrm{h}$.[9]

\section{SYNROC PROCESSES}

The literature has indicated several routes for making Synroc or hollandite. Multiphase ceramics are suitable for wastes that do not contain a significant proportion of glass forming components. They can be formed with a wide range of process technologies including sintering, hot-isostatic pressing (HIP) in argon and cold-crucible induction melting (CCIM).

\section{Sintering}

Sintering consists of pressing a pellet generally somewhat larger than the desired size and sintering it in a furnace to an appropriate temperature, via a carefully controlled heating/cooling cycle, under the desired atmosphere. Sintering is widely used in the nuclear industry for the production of MOX fuel pellets. To sinter a binder and lubricant must be added to press uniform "green" pellets, and the feed powder must be ground fine ( $~ 10$ microns) and mixed to increase reactivity. This increased reactivity will allow the pellets to be sintered without cracking or unpredictable dimensional changes and will avoid sticking between sintered pellets and furnace equipment provided appropriate setter plates are used.[10] 


\section{HIP}

A HIP consists of a pressure vessel surrounding a resistance-heated furnace. In hot isostatic pressing a stainless steel can is filled with calcined radioactive waste feed and is then evacuated at temperatures up to $\sim 500^{\circ} \mathrm{C}$ and sealed. The can is placed into a furnace and the HIP vessel is closed and pressurized using argon gas. The pressure is applied isostatically via the dense high pressure argon, which is also an extremely efficient conductor of heat. This combined effect consolidates and immobilizes the waste into a dense isotropic monolithic block sealed within the can. HIPs are used in the nuclear industry and are installed in hot-cell facilities.[10]

There are several methods of making the HIP precursor. In one approach, the waste is added to a mechanical mixture of the binary metal oxides necessary for formation of Synroc and calcined in a reducing gas. This mixture is sealed in canisters and HIPed at $\sim 10^{8} \mathrm{~Pa}$ and $1200-1400^{\circ} \mathrm{C}$.[11] A variation on this is known as the standard sol-gel route in which an alkoxide based liquid precursor is hydrolyzed by mixing with an aqueous waste stream, dried, calcined under reducing conditions and hot-pressed in metal bellows at $1200^{\circ} \mathrm{C} / 14-20 \mathrm{MPa}$ after adding $2 \mathrm{wt} \%$ Ti metal as an oxygen getter.[12] The Synroc precursor can also be made via a chemical processing route involving Ti and $\mathrm{Zr}$ alkoxide hydrolysis in the presence of $\mathrm{NaOH}$ to form a sodium titanate/zirconate powder which acts as a cation exchanger for $\mathrm{Al}, \mathrm{Ba}$, and $\mathrm{Ca}$ waste nitrate solutions. This form is dried and then calcined under reducing conditions and hot pressed and sintered at 1100$1170^{\circ} \mathrm{C}$, with the addition of $2 \mathrm{wt} \%$ Ti to lower the mobility of the volatiles and keep Mo metallic to avoid the formation of water soluble molybdates.[13]

Cesium is volatile and is highly mobile in the environment, and together cesium and strontium account for the majority of radiogenic heat generated in fission product wastes. The integration of waste form and process design enables the elimination of volatility concerns during consolidation by the use of hot-isostatic pressing technology. This is achievable, even at high temperatures, since the waste form is sealed inside a stainless steel can prior to HIPing. By overcoming volatility concerns during consolidation, the tailored waste forms also relieve pressure on the off-gas requirements resulting in further cost savings. The combination of high temperature and high pressure used with the HIP can cause safety concerns in radioactive waste environments, especially those dealing with plutonium. In contrast, encapsulation of the waste in glass uses high temperatures but atmospheric pressures.

\section{Melting/CCIM}

Synroc can be formed by melting oxides into a glass composite material. Glass ceramics (crystalline) are made by melting to form a viscous glass, which is then crystallized on cooling or in a separate crystallizing heat treatment operation. Controlled crystallization can be used to form desired phases rather than uncontrolled devitrification of a vitreous waste form. Uncontrolled crystallization can lead to potential stress and cracking or reduced durability. With controlled crystallization, there is a potential for higher waste loadings, and improved mechanical and chemical properties compared to the parent glass. 
The latter can be achieved by controlled partitioning to incorporate highly active species into crystals while leaving a continuous glassy phase of similar composition and durability to that of the current waste immobilization glasses. To reduce the number of processing steps it is desirable to use controlled cooling from the melt to give the desired microstructure and phase evolution rather than a separate heat treatment. The crystallization sequence in such systems is a strong function of waste loading and cooling history, often with undesirable surface and bulk nucleation. Synroc glass ceramic is an example of a glass ceramic with Synroc crystalline phases in a vitreous matrix, which was developed for sodium rich wastes such as those from the Hanford site.[13]

One technology capable of achieving this melting scheme is the cold crucible melter, which consists of water-cooled metal fingers that surround the material to be melted. The crucible, surrounded by an induction coil, is essentially transparent to the electromagnetic field and direct heating of the material in the crucible is possible without an electrode inside the melter. Once melting is established, a frozen skull of the material being melted solidifies on the cold walls and forms a protective self-healing and corrosion-resistant barrier that protects the rest of the melter from melt corrosion. Cold crucible melters are better suited to large scale continuous rather than batch operation, as startup can be difficult. However they operate at higher temperatures than joule melters and produce less secondary waste. To initiate each melt batch, species susceptible to conductive material need to be added. These are typically refractory metals (such as $\mathrm{Ti}$ or $\mathrm{Zr}$ ), which allows the surrounding material to be heated to a temperature where it can couple directly with the induction field. This coupling requirement can place a relatively narrow specification on the waste form chemistry as the overall composition of the melt needs to meet certain electrical properties and thermal conductivity requirements, as well as viscosity and melting rate characteristics, to allow the process to be sustainable without breaching its confining chilled skull and yet be poured safely.[10]

\section{IMMOBILIZATION OF Cs AND Sr WITH SYNROC}

Important factors in determining the applicability of using Synroc for immobilization of $\mathrm{Cs}$ and $\mathrm{Sr}$ include the potential waste loading (to reduce storage space requirements), the chemical durability (to reduce leach resistance as compared to borosilicate glass) and the waste form flexibility (to allow for feed/process variations). Much research has been completed in the past 20 years on the development of Synroc for various types of Cs and $\mathrm{Sr}$ waste streams and a small portion of that work is related here.

\section{Leach test definitions}

Before discussing the results of some of the testing, an understanding of the various leach tests conducted may be helpful. In general, leach testing was conducted on the various Synroc-type products to compare the chemical durability with that of borosilicate glass. The main vitreous waste form leach tests include:

- MCC-1 uses deionized water in static conditions on a monolithic specimen with the sample surface to water volume usually $10 \mathrm{~m}^{-1}$ and is usually conducted at 
$90^{\circ} \mathrm{C}$. (MCC is the Materials Characterization Center of Pacific Northwest National Laboratory (PNNL).)

- MCC-2 uses deionized water in static conditions on a monolithic specimen at an elevated temperature in a closed system.

- MCC-3 (or Performance Consistency Test (PCT) - ASTM C1285-94) uses deionized water at $90^{\circ} \mathrm{C}$ on a powder sample in a closed system with a surface area to water volume of $\sim 1000 \mathrm{~m}^{-1}$.

- MCC-4 uses a single pass flow-through test with deionized water in a system that is open to the atmosphere

- MCC-5 uses a high flow Soxhlet in a system that is open to the atmosphere.

\section{Results of literature search}

Following are brief descriptions of the results of a literature survey that focused on the immobilization of $\mathrm{Cs}$ and $\mathrm{Sr}$.

\section{Australia, 1996 [12]}

In 1996, ANSTO reported on immobilization of Tc, Cs and $\mathrm{Sr}$ in Synroc. Cs-doped samples were made by the sol-gel route in which an alkoxide based liquid precursor plus nitrates and $\mathrm{TcO}_{4}{ }^{-2}$ is hydrolyzed, dried, calcined under reducing conditions at $600-750^{\circ} \mathrm{C}$ and hot pressed at $1200^{\circ} \mathrm{C} / 20 \mathrm{MPa}$ in stainless steel. Leaching studies on the resulting samples were then completed.

For $\mathrm{Cs} / \mathrm{Sr}$ incorporation in a Synroc-related mixture, ANSTO used a $70 \mathrm{wt} \%$ hollandite, $20 \mathrm{wt} \%$ perovskite and $10 \mathrm{wt} \%$ rutile material containing $5 \mathrm{wt} \% \mathrm{Cs}$ nominally substituted in the hollandite and $2.5 \mathrm{wt} \%$ of $\mathrm{Sr}$ substituted in the perovskite. The formulation was based on a hollandite composition of $\mathrm{Ba}_{0.8} \mathrm{Cs}_{0.4}\left(\mathrm{Ti}_{1.5} \mathrm{Al}_{0.5}\right) \mathrm{Ti}_{6} \mathrm{O}_{16}$, with the perovskite composition being given by $\mathrm{Ca}_{0.79} \mathrm{Sr}_{0.21} \mathrm{TiO}_{3}$. The material had a composition of $2.3 \mathrm{wt} \%$ $\mathrm{Al}_{2} \mathrm{O}_{3}, 10.8 \mathrm{wt} \% \mathrm{BaO}, 6.1 \mathrm{wt} \% \mathrm{CaO} ; 5.1 \mathrm{wt} \% \mathrm{Cs}_{2} \mathrm{O} ; 3 \mathrm{wt} \% \mathrm{SrO} ; 72.7 \mathrm{wt} \% \mathrm{TiO}_{2}$. The grain size was $<1 \mu \mathrm{m}$ and the overall density was $4.2 \mathrm{~g} / \mathrm{cm}^{3}$. Both MCC-1 and PCT tests were completed at $90^{\circ} \mathrm{C}$ for 184 and 84 days respectively. Cs leach rates were 0.15 $\mathrm{g} / \mathrm{m}^{2} /$ day for the first 7 days and then fell to $0.01-0.03 \mathrm{~g} / \mathrm{m}^{2} /$ day. Sr leach rates were $<0.01-0.02 \mathrm{~g} / \mathrm{m}^{2} /$ day.

Cs and $\mathrm{Sr}$, in a molar ratio of 2:1, were also added to a Synroc-B form with an approximate composition of $5.4 \mathrm{wt} \% \mathrm{Al}_{2} \mathrm{O}_{3}, 5.6 \mathrm{wt} \% \mathrm{BaO}, 11 \mathrm{wt} \% \mathrm{CaO}, 71.4 \mathrm{wt} \% \mathrm{TiO}_{2}$ and $6.6 \mathrm{wt} \% \mathrm{SrO}_{2}$. It was not experimentally clear whether Cs preferentially entered the hollandite or reacted to form Cs aluminates such as $\mathrm{CsAlO}_{2}$ or $\mathrm{Cs}_{2} \mathrm{Al}_{22} \mathrm{O}_{34}$ although there was no indication that the $\mathrm{Cs}$ was in phases other than hollandite.

At high Cs loadings, the presence of enough $\mathrm{TiO}_{2}$ is important in allowing incorporation of $\mathrm{Cs}$ in hollandite. If enough is present, it is assumed that all $\mathrm{Cs}$ and $\mathrm{Ba}$ form hollandite according to $\mathrm{Ba}_{\mathrm{x}} \mathrm{Cs}_{\mathrm{y}}\left(\mathrm{Al}, \mathrm{Ti}^{3+}\right)_{2 \mathrm{x}+\mathrm{y}}\left(\mathrm{Ti}^{4+}{ }_{8-2 \mathrm{x}-\mathrm{y}}\right) \mathrm{O}_{16}$. The limiting case can be calculated as $\mathrm{x}=0.40$ and $\mathrm{y}=0.81$ corresponding to a Cs loading of $9 \mathrm{wt} . \%$. The effect of small additions of $\mathrm{Sr}$, in a 1:2 molar ratio relative to $\mathrm{Cs}$, was found to affect the maximum $\mathrm{Cs}$ loading by $<0.5$ wt. $\%$. 
Cs loading may be more limited by the temperature requirements at the storage facility or repository. For a Synroc bellows $0.35 \mathrm{~m}$ in diameter, and containing $100 \mathrm{~kg}$ of Synroc, the heat loading from the $\mathrm{Cs}$ at $10 \mathrm{wt} . \% \mathrm{Cs}_{2} \mathrm{O}$ would correspond to a centerline temperature of $300-400^{\circ} \mathrm{C}$, disqualifying it from any repository where the temperature was required to be $<100^{\circ} \mathrm{C}$.

The conclusion from this study was that $\mathrm{Cs}$ and $\mathrm{Sr}$ can be suitably immobilized in hollandite-rich Synroc variants, when precautions are taken to suppress formation of CsAlTiO 4 .

Australia / RUSSIA, 1997 [14,15]

In 1997, ANSTO worked with the SIA "Radon" and the Institute of Geology of Ore Deposits in Moscow, Russia on a comparative study of Synroc ceramics. Since 1990 development and testing of the cold crucible technology for Synroc production have been carried out at SIA "Radon". Three Synroc-C samples containing simulated high level waste were studied. One was produced by the conventional hot-pressing method at ANSTO (sol-gel precursors, calcination, hot-pressing at $1150-1200^{\circ} \mathrm{C}$ and $14-21 \mathrm{MPa}$ ) and the others were obtained using cold crucible technology at Radon, Russia using an air atmosphere. One of the melted samples was prepared using the ANSTO sol-gel precursor and the second one was obtained from an oxide-nitrate mixture.

The specimens had closely similar mineral compositions with major hollandite, perovskite, zirconolite, and rutile phases. Molybdenum in the melted Synrocs exists in the form of $\mathrm{Ba}-\mathrm{Ca}$ and $\mathrm{Ca}-\mathrm{Sr}$ molybdates rather than metal alloy as in hot-pressed Synrocs. Cs in the melted samples enters molybdates, while in the hot-pressed Synroc this element enters hollandite. Thus fixation of the Cs in the melted Synrocs was substantially lower compared to the hot-pressed Synroc due to the formation of molybdates under oxidizing melting process conditions. In order to avoid molybdates formation, the melting process must be performed under reducing conditions. Leaching of other components (Ti, Zr) was comparable with that in hot-pressed Synroc.

Samples prepared from the various routes described above were used for additional leaching tests. The leaching experiments were conducted on powdered samples at room temperature, $100^{\circ} \mathrm{C}$, and $200^{\circ} \mathrm{C}$ by repeated static tests with regular replacement of deionized water leachant.

Leaching behavior of the CCIM generated samples was mainly governed by the presence of alkali molybdates. The results indicated that $40-50 \%$ of the Cs is present in the molybdates. The Cs concentration in the leachate for the CCIM prepared samples was 40-160 ppm and in the hot-pressed sample was $0.5 \mathrm{ppm}$ when leached at room temperature. At elevated temperatures $\mathrm{Cs}$ exhibited the highest leach rate for the CCIM samples $\left(\sim 0.1-5 \mathrm{~g} / \mathrm{m}^{2} /\right.$ day $)$. These rates were approximately the same as those obtained from borosilicate glass $\left(\sim 1-10 \mathrm{~g} / \mathrm{m}^{2} /\right.$ day $)$ and about two orders of magnitude higher than the leach rates for hot-pressed Synroc samples $\left(\sim 0.005-0.1 \mathrm{~g} / \mathrm{m}^{2} /\right.$ day $)$. 
In summary, Cs and Mo leachability of samples prepared by inductive melting in the cold crucible indicate that the cesium leachability is close to that of borosilicate glass. The yield is determined by the presence of highly soluble alkali molybdates, which contain about half of total Cs. In order to avoid the formation of alkali molybdates the Synroc melting should be carried out at strongly reducing conditions where the alkali molybdates are thermodynamically unstable or alkali elements must be separated from HLW according to HLW partitioning concept.

Australia, 2001 [16] In 2001, ANSTO studied the aqueous durability of Rb-doped Synroc and hollandite. Rb hollandite and Synroc containing a modified Purex-type high level nuclear waste were produced by alkoxide/nitrate route. This method involved the mixing of the correct molar quantities of Al sec-butoixde, tetrabutyl zirconate and isopropyl titanate in ethanol with nitrates dissolved in water, while continuously stirring. Mixtures were then heated and stirred to drive off the alcohol and water. The dry product was calcined in air for two hours at $750^{\circ} \mathrm{C}$ and then ball-milled. The samples were hot-pressed at $21 \mathrm{MPa}$, with and without $2 \mathrm{wt} \%$ Ti metal added, for 2-10 hours at temperatures between $1200-1250^{\circ} \mathrm{C}$ in a graphite die.

The Synroc samples were leached at $90^{\circ} \mathrm{C}$ and showed the $\mathrm{Ba}\left(\sim 0.01 \mathrm{~g} / \mathrm{m}^{2} /\right.$ day initially, falling to $\sim 0.08 \mathrm{~g} / \mathrm{m}^{2} /$ day at 128 days $)$ and Cs $\left(\sim 0.8 \mathrm{~g} / \mathrm{m}^{2} /\right.$ day initially, falling to $\sim 0.007$ $\mathrm{g} / \mathrm{m}^{2} /$ day after 128 days) leach rates broadly similar to reference grade Synroc-C. $\mathrm{Rb}$ leaching from all samples was relatively low and broadly similar to that of $\mathrm{Cs}$ and $\mathrm{Ba}$ in hollandite. However, the $\mathrm{Rb}$ normalized leach rates did not continue a downward trend with increasing time as do the Ba leach results. Earlier work on a hollandite rich Synroc showed that when very low quantities $(<1 \%)$ of the water-soluble $\mathrm{CsAlTiO}_{4}$ phase were present in the Synroc sample, the Cs normalized leach rates did not follow a downward trend. As there is not an $\mathrm{Rb}$ analog of the $\mathrm{CaAlTiO}_{4}$ phase and only a very small amount of $\mathrm{Rb}$ was found in some of the perovskite, the exact reason for the $\mathrm{Rb}$ leach rates not following those of the Ba-hollandite, or behaving like Cs in hollandite, is not known.

\section{Australia, 2002 [5]}

In 2002, ANSTO reported on hollandite studies that included fabrication, characterization and leach testing. Ba hollandite samples containing 0.5 formula units of extra $\mathrm{TiO}_{2}$ in the rutile form were produced by the alkoxide route. This method involved mixing the correct molar quantities of aluminum sec-butoxide and titanium (IV) isopropoxide in ethanol with $\mathrm{Ba}$ nitrate (and $\mathrm{Cs}$ nitrate where necessary) dissolved in water, under continuous stirring. The mixture was then heated to approximately $110^{\circ} \mathrm{C}$ to drive off the alcohol and water and stirred. The dry product was then calcined in air for two hours at $750^{\circ} \mathrm{C}$ and then wet milled. The samples were hot uniaxially pressed in $40 \mathrm{~mm}$ diameter graphite dies for 10 hours at $21 \mathrm{MPa}$ at temperatures between $1200^{\circ} \mathrm{C}$ and $1250^{\circ} \mathrm{C}$.

The normalized $\mathrm{Ba}$ and $\mathrm{Cs}$ release rates of these samples at $90^{\circ} \mathrm{C}$ in deionized water were $<0.001 \mathrm{~g} / \mathrm{m}^{2} /$ day after 56 days, and decreased with increasing leaching times. Varying the $\mathrm{pH}$ of between 2.5 and 12.9 affected only the Ba dissolution rates of hollandite by half an order of magnitude. The dissolution rates of all species decreased with increasing 
leach time due to the formation of partly impervious surface coatings of $\mathrm{Al}$ and $\mathrm{Ti}$ rich species.

Australia, 2004 [17]

In 2004, ANSTO reported on studies conducted with hollandite-rich ceramic melts for immobilization of Cs. The titanate Synroc phase hollandite $\left(\mathrm{Ba}_{\mathrm{x}} \mathrm{Cs}_{\mathrm{y}} M^{3+}{ }_{2 \mathrm{x}-\mathrm{y}} \mathrm{Ti}_{8-2 \mathrm{x}-\mathrm{y}} \mathrm{O}_{16}\right.$ where trivalent $M=\mathrm{Al}$ in oxidizing conditions and $\mathrm{Al}$ and $\mathrm{Ti}$ in reducing conditions) is well known for its ability to incorporate $\mathrm{Cs}$ when produced by hot pressing with excellent leach resistance. But attempts to melt (hollandite-bearing) Synroc C under air atmospheres resulted in all Synroc titanate phases, including hollandite, being formed, but leachable Cs molybdate phases due to the presence of $\mathrm{Mo}^{6+}$ were also observed.

They found that the Cs did not enter the hollandite phase in melted Synroc-C and in order to incorporate the $\mathrm{Cs}$ in the hollandite the Synroc-C metals had to be processed under reducing atmospheres.

ANSTO's criteria for a suitable waste form included (a) could be melted in air; (b) no readily leachable phases were apparently present; (c) leach rates were low $(<1 \mathrm{~g} / \mathrm{l}$, PCTB) and (d) low Cs volatility. Samples for melting were produced by mixing the correct molar quantities of aluminum sec-butoxide (where necessary), titanium (IV) isopropoxide and zirconium tertbutoxide in ethanol with nitrates of other components dissolved in water, while continuously stirring. The mixture was then heated to $\sim 110^{\circ} \mathrm{C}$ to drive off the alcohol and water, while continuously stirring. The dry product was then calcined in air for two hours at $750^{\circ} \mathrm{C}$. The samples were placed in Pt crucibles and melted in air at $1450-1550^{\circ} \mathrm{C}$. Samples for sintering were prepared up to the calcination stage then wet ball milled in cyclohexane and sintered in air at $1300^{\circ} \mathrm{C}$ for 20 hours. All sintered samples were made with an additional 0.5 moles of $\mathrm{TiO}_{2}$.

PCT leach testing was carried out on a selection of samples, which were free of $\mathrm{Cs}_{2} \mathrm{O}$ and $\mathrm{Cs}$ titanate phases. The normalized $\mathrm{Cs}$ leachate concentrations for the $M=\mathrm{Cr}, \mathrm{Ni}$ and $\mathrm{Co}$ samples were $0.15 \mathrm{~g} / 1,0.15 \mathrm{~g} / \mathrm{l}$ and $0.08 \mathrm{~g} / 1$ respectively. These results are similar to those of other titanate hollandite-rich melts. The PCT leachate concentrations for $\mathrm{Na}, \mathrm{Li}$ and $\mathrm{K}$ in EA glass are around $14 \mathrm{~g} / \mathrm{l}$ and as $\mathrm{Cs}, \mathrm{Na}, \mathrm{Li}$, and $\mathrm{K}$ are all alkalis they should have comparable normalized leach rates in such tests. The alkali normalized leachate concentrations in glass have values, which are two orders of magnitude above these studies lowest Cs concentrations. The normalized Cs leachate concentrations are comparable to those from reference Synroc-C.

In summary, leach resistant titanate hollandite-rich ceramics incorporating $\sim 7.5 \mathrm{wt} \% \mathrm{Cs}$ can be prepared with the hollandite in the sample containing $\mathrm{Cr}^{3+}, \mathrm{Ni}^{2+}, \mathrm{Zn}^{2+}$ or $\mathrm{Co}^{2+}$ (compensated by $\mathrm{Ti}^{4+}$ where necessary) by melting in air, as well as by ceramic technology. The normalized PCT-B Cs leachate concentrations for the melted samples are two orders of magnitude better than the $\mathrm{Na}, \mathrm{B}$ and $\mathrm{Li}$ concentrations for reference glass. A hollandite-rich melted ceramic containing $\mathrm{Mg}$ did not result in the $\mathrm{Cs}$ being incorporated in hollandite and was thus not a feasible waste form. The hollandite-rich Mn sample melted in air designed to investigate the minimum number of phases showed feasible waste forms could be made with only the addition of perovskite and rutile to the 
major hollandite. Cs could be fully substituted for $\mathrm{Ba}$ in single-phase hollandite $\mathrm{Ba}_{\mathrm{x}} \mathrm{Cs}_{\mathrm{y}}\left(\mathrm{Cr}^{3+}\right)_{2 \mathrm{x}+\mathrm{y}} \mathrm{Ti}_{8-2 \mathrm{x}-\mathrm{y}} \mathrm{O}_{16}$ and $\mathrm{Ba}_{\mathrm{x}} \mathrm{Cs}_{\mathrm{y}}\left(M^{2+}\right)_{\mathrm{x}+\mathrm{y} / 2} \mathrm{Ti}_{8-\mathrm{x}-\mathrm{y} / 2} \mathrm{O}_{16}$ where $M=\mathrm{Ni}$ or Co in airsintered samples.

\section{Australia, 2004 [18]}

In 2004, ANSTO reported on testing on hollandite-rich titanate ceramics prepared by melting in air by replacing the $\mathrm{Al}$ in the hollandite with cations of larger ionic radii $(\mathrm{Ga}$, $\mathrm{Fe}$, and $\mathrm{Mn}$ ) to expand the tunnels in the structure and thus facilitating the entry of Cs. This was done by replacing the $\mathrm{Al}_{2} \mathrm{O}_{3}$ in the precursor mix with the same wt $\%$ of $\mathrm{Ga}, \mathrm{Fe}$ and Mn oxides (assuming they were in the +3 state). The samples were produced by the alkoxide route.

The Synroc-B with $7.5 \mathrm{wt} . \% \mathrm{Cs}_{2} \mathrm{O}$ in hollandite-rich $\mathrm{Al}$ was melted in air at $1550^{\circ} \mathrm{C}$. It contained about $50 \%$ hollandite plus zirconolite, perovskite, rutile and $\mathrm{Cs}_{2} \mathrm{Al}_{2} \mathrm{Ti}_{2} \mathrm{O}_{8}$. The small amount of highly leachable $\mathrm{Cs}_{2} \mathrm{Al}_{2} \mathrm{Ti}_{2} \mathrm{O}_{8}$ (containing $<1 \%$ of the Cs inventory) rendered the sample unsuitable for a waste form. Analysis of these sample results indicated that the addition of additional titanate phases would not only reduce melting temperature but also aid in the incorporation of the Cs in the hollandite structure.

The hollandite-rich Ga sample was melted in air at $1550^{\circ} \mathrm{C}$ and contained mostly hollandite, which contained the majority of the $\mathrm{Cs}$, and rutile with minor components being zirconolite, perovskite, $\mathrm{Cs}_{2} \mathrm{Ga}_{2} \mathrm{Ti}_{2} \mathrm{O}_{8}$, and $\mathrm{Cs}$ titanate. Since $\mathrm{Cs}_{2} \mathrm{Ga}_{2} \mathrm{Ti}_{2} \mathrm{O}_{8}$ is very reactive in water, samples containing this phase were regarded as unsuitable waste forms.

The hollandite-rich Fe samples were melted in air at $1500^{\circ} \mathrm{C}$ and hollandite-rich $\mathrm{Fe} / \mathrm{K}$ sample in air at $1450^{\circ} \mathrm{C}$ and contained Cs-bearing hollandite, zirconolite, perovskite, rutile and $\mathrm{Cs}$ titanate. The addition of more $\mathrm{Fe}_{2} \mathrm{O}_{3}$ and $\mathrm{BaO}$ to the precursor resulted in a sample that did not contain the leachable Cs titanate phase. Therefore, this mixture was deemed to have a composition suitable for a waste form. The $\mathrm{K}$ was added to the mix in an attempt to lower the melting temperature and the hollandite-rich $\mathrm{Fe} / \mathrm{K}$ composition was also deemed to be suitable as a waste form as it contained no leachable phases.

The hollandite-rich $\mathrm{Mn}$ sample was melted in air at $1550^{\circ} \mathrm{C}$ and contained mostly Csbearing hollandite, zirconolite and perovskite and rutile. It lacked any easily leachable Cs-rich phases, which suggests this also would be an appropriate waste form composition.

PCT-B leach testing was carried out on the air melted hollandite-rich Fe and Mn samples. The leach results for the samples containing Fe (normalized Cs leachate concentration of $2.39 \mathrm{~g} / \mathrm{l}$ ) were appreciably higher than those for the other samples reflecting the presence of Cs titanate in this sample. In the modified sample containing Fe, which did not contain $\mathrm{Cs}$ titanate, the normalized Cs leachate concentration was reduced to $0.12 \mathrm{~g} / \mathrm{l}$. The leachate concentration for the Fe/K sample was $0.62 \mathrm{~g} / 1$ and for the Mn sample was 0.27 $\mathrm{g} / 1$. For comparison, the leachate concentration for reference EA glass is 13-16 g/l. 
In summary, leach resistant titanate hollandite-rich ceramic melts incorporating $\sim 7.5 \mathrm{wt} \%$ $\mathrm{Cs}_{2} \mathrm{O}$ were prepared when the hollandite in the sample contained $\mathrm{Fe}$ (when $\mathrm{BaO}$ added with extra $\mathrm{Fe}_{2} \mathrm{O}_{3}$ ) or $\mathrm{Mn}$.

\section{France, 2004 [6]}

The synthesis, characterization and study of the radiation effects on hollandite ceramics developed for Cs immobilization were studied. Several hollandite samples having the $\mathrm{Ba}^{2+}{ }_{\mathrm{x}} \mathrm{Cs}_{\mathrm{y}}^{+}(\mathrm{Al}, \mathrm{Fe})^{3+}{ }_{2 \mathrm{x}+\mathrm{y}} \mathrm{Ti}^{+{ }^{++}}{ }_{8-2 \mathrm{x}-\mathrm{y}} \mathrm{O}_{16}$ composition type $(1.16 \leq \mathrm{x} \leq 1.28 ; 0 \leq \mathrm{y} \leq 0.28$; with or without $\mathrm{Fe}$ ) were prepared in air. One sample was chosen near the lower limit of the compositional range of $\mathrm{Ba}-\mathrm{Al}$ hollandite (without $\mathrm{Fe}$ ) in order to insert $\mathrm{Cs}$ more easily. In another sample, part of the $\mathrm{Ba}$ was substituted by $0.1 \mathrm{Cs} /$ formula unit, keeping constant the $\mathrm{Al} / \mathrm{Ti}$ ratio. Another sample used $\mathrm{Fe}^{3+}$ to partly replace $\mathrm{Al}^{3+}$ ions to facilitate incorporation of $\mathrm{Cs}$ into the tunnels. All samples were prepared by mixing $\mathrm{Al}_{2} \mathrm{O}_{3}, \mathrm{Fe}_{2} \mathrm{O}_{3}$, $\mathrm{TiO}_{2}, \mathrm{BaCO}_{3}$ or $\mathrm{CsNO}_{3}$ powders, pelletizing and calcining the mixture for 4 hours at $810^{\circ} \mathrm{C}$. The calcined powders were ground and sintered at $1320^{\circ} \mathrm{C}$ for 96 hours or at $1200^{\circ} \mathrm{C}$ for 30 hours.

This study showed that single phase hollandite ceramics in the $\mathrm{Ba}_{\mathrm{x}}(\mathrm{Al}, \mathrm{Fe})^{3+}{ }_{2 \mathrm{x}} \mathrm{Ti}^{4+}{ }_{8-2 \mathrm{x}} \mathrm{O}_{16}$ compositional range can be obtained by natural sintering under air of oxide powders (oxide route). To insert $\mathrm{Cs}$ in the structure, the substitution of $\mathrm{Al}^{3+}$ by $\mathrm{Fe}^{3+}$ ions in hollandite composition, which increases the lattice parameters, seems to be necessary. Thus, iron-substituted barium hollandite, prepared by either an alkoxide or an oxide route produces waste forms suitable for Cs immobilization.

\section{France, 2004 [19]}

Additional work by the CEA (Commissariat à l'Energie Atomique) in 2004 included other studies on iron-substituted barium hollandite for Cs immobilization. A five wt $\%$ $\mathrm{Cs}_{2} \mathrm{O}$-doped Fe substituted hollandite was synthesized on a laboratory scale (100g), using an alcoxide route. The hollandite crystallization was achieved after a 5-hour calcination at $1000^{\circ} \mathrm{C}$, in air atmosphere. After milling and cold pressing steps, ceramic pellets were sintered in air at $1250^{\circ} \mathrm{C}$ for 15 hours. The resulting materials were dense single phase pellets. The leaching resistance of this material was measured in pure water at $100^{\circ} \mathrm{C}$ using Soxhlet tests. The initial alteration rates in pure water at $100^{\circ} \mathrm{C}$ are in the range of $10^{-3} \mathrm{~g} / \mathrm{m}^{2} /$ day for tests conducted for 56 days in a continuously renewed pure water flow $\left(0.02 \mathrm{~g} / \mathrm{m}^{2} /\right.$ day on first day, $0.0006 \mathrm{~g} / \mathrm{m}^{2} /$ day between 25 and 56 days $)$.

France, 2005 [20]

Continued testing on the chemical durability of iron-substituted hollandite ceramics for Cs immobilization was reported in 2005 by the CEA. Samples from the 2004 tests were leached under static conditions for 1 year at $90^{\circ} \mathrm{C}$. Under static conditions the mean alteration rate measured between 0 and 7 days was about $2 \times 10^{-3} \mathrm{~g} / \mathrm{m}^{2} / \mathrm{d}$. Between 7 and 30 days the rate dropped to about $8 \times 10^{-5} \mathrm{~g} / \mathrm{m}^{2} / \mathrm{d}$. The residual rate over longer durations was less than $10^{-5} \mathrm{~g} / \mathrm{m}^{2} /$ day. These results confirm the Cs-specific immobilization potential of iron-substituted hollandite ceramics. 
CEA is continuing characterization of the material performance with emphasis on the effects of temperature, $\mathrm{pH}$ and surface area/volume ratio on the alteration rate, and on the self-irradiation behavior of the material. Other work is also in progress to determine the parameters related to the technological feasibility of these matrices, and in particular to establish a composition range around the reference composition for suitable management of chemical impurities liable to be present in the waste stream.

\section{U.K., 2004 [7]}

The U.K. has also been involved in studies of hollandite-based radioactive waste forms. In 2004, they reported on structural studies on hollandites with compositions $\mathrm{Ba}_{1.2-\mathrm{x}} \mathrm{Cs}_{\mathrm{x}} \mathrm{Mg}_{1.2-\mathrm{x} / 2} \mathrm{Ti}_{6.8+\mathrm{x} / 2} \mathrm{O}_{16}$ and $\mathrm{Ba}_{1.2-\mathrm{x}} \mathrm{Cs}_{\mathrm{x}} \mathrm{Al}_{2.4-\mathrm{x}} \mathrm{Ti}_{5.6+\mathrm{x}} \mathrm{O}_{16}(\mathrm{x}=0,0.1,0.25)$ that were made using a modified alkoxide/acetate precursor route and then either using HIP or sintering for the final product. X-ray powder diffraction showed that both methods yielded samples with tetragonal hollandites. When prepared by HIP the samples showed a greater degree of crystallinity. The data showed that the Cs is located within the channels in the structure, with no evidence of secondary phases.

\section{$\underline{\text { Russia, } 2003}$ [21]}

In 2003, the Russian Academy of Sciences reported on the synthesis and study of isomorphous miscibility limits of crystalline phases with hollandite-type tunnel structure in the $\mathrm{CsO}(\mathrm{MeO})-\mathrm{Al}_{2} \mathrm{O}_{3}-\mathrm{TiO}_{2}(\mathrm{Me}=\mathrm{Ba}, \mathrm{Sr})$ systems. Samples were prepared by the solid phase synthesis of $\mathrm{TiO}_{2}, \mathrm{Al}_{2} \mathrm{O}_{3}, \mathrm{BaCO}_{3}, \mathrm{Cs}_{2} \mathrm{CO}_{3}$, and $\mathrm{SrCO}_{3}$. The Cs containing samples went through a three-stage heat treatment with intermediate grinding of cakes after sintering at $650^{\circ} \mathrm{C}, 950^{\circ} \mathrm{C}$ and $1300^{\circ} \mathrm{C}$ for $18-36$ hours. After heat treatment the sample was quenched in air. The Sr containing samples were sintered at temperatures of $950^{\circ} \mathrm{C}$ and $1300^{\circ} \mathrm{C}$.

The variations in the temperature and duration of heat treatment in the course of synthesis resulted in the formation of the final products containing, as a rule, a mixture of two phases, namely hollandite and rutile. Through optimization of compositions, it was determined that the composition of the initial mixtures used in the synthesis must be calculated from the following hollandite empirical formula $\mathrm{BaAl}_{2} \mathrm{Ti}_{5} \mathrm{O}_{14}$.

The studies suggested an insignificant volatility of Cs under the experimental conditions indicating the $\mathrm{Cs}^{+}$cations are embedded in the hollandite tunnel positions. They concluded that the region of existence of $\mathrm{Cs}_{\mathrm{x}} \mathrm{Ba}_{1-\mathrm{x} / 2} \mathrm{Al}_{2} \mathrm{Ti}_{5} \mathrm{O}_{14}$ solid solutions lie in the concentration range $0 \leq x \leq 0.7$. It should be noted that the value $x=0.7$ corresponds to a rather high cesium content (13.3 wt.\%) in the crystal lattice of hollandite. For this reason, it would be appear to be appropriate to use these compounds as ceramic matrixes to immobilize cesium-containing radioactive wastes.

In the $\mathrm{SrO}-\mathrm{BaO}-\mathrm{Al}_{2} \mathrm{O}_{3}-\mathrm{TiO}_{2}$ system hollandite based solid solutions were not observed over a wide range of concentrations. At $\mathrm{x}>0.2$, the experimental conditions described above provide the formation of multiphase samples that contain $\mathrm{TiO}_{2}$ and $\mathrm{SrTiO}_{3}$ impurities in addition to the hollandite phase. 


\section{U.S., 1996 [11]}

In 1996, Los Alamos National Laboratory (LANL) performed tests on Synroc-B that had been synthesized at atmospheric pressure from freeze-dried nitrate precursors. By calcining atomically mixed precursors prepared by freeze drying (the cryochemical technique) of rapidly frozen nitrate solutions, the intimate mixing of ions inherent in a solution is conserved. Subsequent removal of the solvent by low temperature sublimation prevented phase separation and transferred this intimate mixture of ions into the solid state. As a result the conventional diffusion limited solid state reaction was circumvented and product formation was allowed to occur very rapidly at lower temperatures.

LANL demonstrated that the complete Synroc-B phase assemblage can be synthesized at ambient pressure (600 torr) through the calcination of atomized mixtures of nitrate salts prepared by freeze drying. Thermal processing of the freeze dried precursor for $10 \mathrm{~min}$ at $1100^{\circ} \mathrm{C}$ or $15 \mathrm{hr}$ at $1000^{\circ} \mathrm{C}$ (in a $6 \% \mathrm{H}_{2} / \mathrm{Ar}$ atmosphere) yielded the desired product. The Synroc phases included $\mathrm{CaTiO}_{3}, \mathrm{CaZrTi}_{2} \mathrm{O}_{7}$ and $\mathrm{BaAl}_{2} \mathrm{Ti}_{15} \mathrm{O}_{14}$ ). The freeze dried powders would still need to be sintered but this should be simpler (lower temperatures) due to their uniform small particle sizes rather than the large and nonuniform particles resulting from calcination of a mechanical mixture.

\section{U.S. and Russia, 2003 [22]}

Results from collaboration between Savannah River Site, INL, PNNL, the V. G. Khlopin Radium Institute and SIA Radon to evaluate CCIM to immobilize Department of Energy (DOE) HLW surrogates was reported in 2003. These lab scale tests with surrogate DOE HLW were promising. Slurry feeding, which had not been widely demonstrated, was proven viable. Batch pouring through a bottom and side drain configuration was also successfully demonstrated. The glass product demonstrated acceptable durability as measured by the PCT. Additional information is needed on the retention of the $\mathrm{Cs}$ and $\mathrm{Sr}$ at the high operating temperatures. Crystal species were detected in some of the products, however, they did not appear to impact processing or measured durability but specific leach rates for Cs were not reported.

\section{U.S., 2004 [23]}

The INL and ANSTO conducted testing to evaluate the feasibility of using a fluidizedbed to convert uranium-bearing liquid waste solutions into a Synroc G precursor. The details of the testing are considered proprietary, but the tests verified the technical feasibility of this approach.

\section{SYNROC / STEAM REFORMING COMPARISON}

As previously stated, safe interim storage of the immobilized Cs/Sr product will require a waste form that is stable, does not produce dangerous radiolysis products (e.g., buildup of potentially explosive gases like hydrogen), has a relatively high product density (to minimize storage volume), and has properties that enhance heat management (e.g., high thermal conductivity). Basically, to meet these fundamental requirements the $\mathrm{Cs} / \mathrm{Sr}$ 
waste stream must be converted from a liquid to a solid while preventing the Cs from volatilizing.

Because simple drying of the $\mathrm{Cs}$ and $\mathrm{Sr}$ in a carbonate solution produces a waste form with unacceptable high aqueous solubility and at high temperatures will decompose and produce $\mathrm{CO}_{2}$, this method will not suffice. In addition, calcination to an oxide form is possible, but the low melting temperature of $\mathrm{Cs}_{2} \mathrm{O}\left(490^{\circ} \mathrm{C}\right)$ limits the size of the disposal container. Regardless, cesium oxide is also hygroscopic and has a low thermal conductivity. In light of these simple processing shortcoming as outlined above, it will be important to identify a immobilization processing technology that also destroys the organics (to prevent a buildup of gases) and ensures no environmental NOx releases preferably by destroyed them.

Since, the specific criterion for the $\mathrm{Cs} / \mathrm{Sr}$ waste form leachability is currently undefined for the $\sim 300-500$ year decay storage time, it may be sufficient to consider the waste canister as the environmental barrier to leaching. Such an assumption may be appropriate, since the criteria for Class C low-level waste (LLW) does not require the material to be stabilized against leaching by allowing the high integrity containers (HICs) to serve as the leachability barrier. Short-lived Cs-137 $\left(\mathrm{t}_{1 / 2}=30.17\right.$ years $)$ contributes to the short term heat load, but Cs-135 $\left(\mathrm{t}_{1 / 2}=3 \times 10^{6}\right.$ years $)$ contributes to the long term radiotoxicity. Current regulations do not limit the quantity of Cs-135 in LLW, but the quantities associated with spent fuel may cause concerns enough to require deep geological disposal. Therefore, to ensure that the $\mathrm{Cs} / \mathrm{Sr}$ product will not require further treatment after the decay storage time, the most conservative approach is to ensure the leachability of the $\mathrm{Cs} / \mathrm{Sr}$ waste form is at least equivalent to that obtained with HLW in borosilicate glasses.

Two extensively developed methods of obtaining a stable $\mathrm{Cs} / \mathrm{Sr}$ waste form equivalent to borosilicate glass include ANSTO's developed Synroc waste form and a steam reforming process that creates a stable mineralized waste form. In steam reforming, the waste feed, superheated steam, and co-reactants are introduced into a fluidized bed steam reformer system where liquids are evaporated; organics are destroyed; and reactive chemicals, radionuclides, and non-volatile heavy metals are converted into a mineralized solid waste product. Ongoing laboratory evaluations of steam reforming for the Cs/Sr stream have indicated the $\mathrm{Cs}$ and $\mathrm{Sr}$ in the solutions can be converted into leach-resistant aluminosilicate minerals, such as pollucite.[24] In order to produce pollucite and other mineral analogs of the alkaline metals, the feed must be mixed with alumino-silicate compounds such as natural clays and subsequently thermally sintered or calcined to activate solid-state crystal formation.

A preliminary evaluation of the effectiveness of employing Synroc's crystalline based waste formulation compared to the use of steam reforming to obtain a stable mineralized waste form has been conducted and is summarized in Table 2. The table highlights various areas of each technology's effectiveness in its ability to sequester the Cs and $\mathrm{Sr}$ fission products that may be selectively removed from any HLW generated by future nuclear fuel reprocessing scenarios. 
TABLE 2. Comparison of Synroc and Steam Reforming

\begin{tabular}{|c|c|c|}
\hline ATTRIBUTES & STEAM REFORMING & SYNROC \\
\hline $\mathrm{Cs} / \mathrm{Sr}$ capture & $\begin{array}{l}\text { Ongoing tests indicate that a } \\
\text { mineralized granular product is formed } \\
\text { with very little volatilization of the } \\
\text { Cs. }[28,29,30]\end{array}$ & $\begin{array}{l}\text { Studies indicate that Synroc processes } \\
\text { capture Cs/Sr in the waste form with } \\
\text { very little volatilization. }[25,34]\end{array}$ \\
\hline Waste Form Durability & $\begin{array}{l}\text { Some Cs/Sr waste stream mineralized } \\
\text { product has been produced, however, } \\
\text { further validation and leach testing is } \\
\text { required. The process destroys the } \\
\text { organics, which could form dangerous } \\
\text { radiolysis products.[28,29,30] }\end{array}$ & $\begin{array}{l}\text { Numerous studies indicate that the } \\
\text { leach rates of Cs/Sr and fission } \\
\text { products from tailored crystalline } \\
\text { waste forms, such as Synroc, are at } \\
\text { least an order of magnitude less than } \\
\text { for the currently accepted borosilicate } \\
\text { glass for HLW. The process also } \\
\text { destroys the organics which could form } \\
\text { dangerous radiolysis products } \\
{[25,26,27,31,32,33,34]}\end{array}$ \\
\hline Waste Form Packaging & $\begin{array}{l}\text { Granular product may require } \\
\text { development of high integrity } \\
\text { packaging to meet existing or future } \\
\text { disposal requirements. Additional } \\
\text { processing may be required, such as } \\
\text { putting the granular product into a } \\
\text { monolithic form, to meet waste } \\
\text { disposal requirements. }[28,29,30]\end{array}$ & $\begin{array}{l}\text { Monolithic waste form in current } \\
\text { standard HLW canister should meet } \\
\text { existing or future disposal } \\
\text { requirements. }\end{array}$ \\
\hline $\begin{array}{l}\text { Formulation and } \\
\text { Processing Complexity }\end{array}$ & $\begin{array}{l}\text { Simple to slightly complicated. Many } \\
\text { steam reformers in production scale } \\
\text { operation for both low level } \\
\text { radioactive waste, hazardous and } \\
\text { hydrogen production. }[28,29,30]\end{array}$ & $\begin{array}{l}\text { Complicated although technology for } \\
\text { processing has been tested at all } \\
\text { scales.[32] }\end{array}$ \\
\hline $\begin{array}{l}\text { Offgas Generation } \\
\text { /Secondary Waste }\end{array}$ & $\begin{array}{l}\text { Offgas generation is less than } \\
\text { incineration -but much greater than } \\
\text { melting or HIPing, Offgas scrubbing } \\
\text { solutions greater than melting or } \\
\text { HIPing -but may be recycled back to } \\
\text { the reformer. NOx is destroyed in the } \\
\text { steam reforming process.[28,29,30] }\end{array}$ & $\begin{array}{l}\text { Low offgas, low offgas scrub } \\
\text { solutions.[32] }\end{array}$ \\
\hline $\begin{array}{l}\text { Processing Flexibility } \\
\text { (Robustness) }\end{array}$ & $\begin{array}{l}\text { Ability to effectively produce } \\
\text { acceptable waste forms for other high - } \\
\text { level waste separated components, } \\
\text { such as Plutonium and Uranium, is } \\
\text { unlikely. }\end{array}$ & $\begin{array}{l}\text { Numerous test indicate Synroc can } \\
\text { sufficiently immobilize any } \\
\text { radionuclides existing in HLW.[25,34] }\end{array}$ \\
\hline
\end{tabular}

\section{CONCLUSION AND PATH FORWARD}

Although this was not an exhaustive literature survey, the articles cited do indicate that immobilization of $\mathrm{Cs}$ and $\mathrm{Sr}$ in a Synroc-type matrix is very feasible.[25,33,34] In general, the hollandite with Cs is chemically durable with a leach resistance two orders of magnitude higher than for the current glass waste forms.[31] The use of tailored, highperformance, alternative waste forms that include ceramics and glass-ceramics [26,27], 
coupled with alternative nearly mature process technologies, such as hot-isostatic pressing, sintering and cold-crucible induction melting [32], offer significant performance improvements and efficiency savings for wastes difficult to incorporate into glass. Many wastes, including those containing $\mathrm{Cs}$ and $\mathrm{Sr}$, are problematic to incorporate in glass, since the limitations of the Joule heated melters used for glass restrict operating temperatures to below $1200^{\circ} \mathrm{C}$, which may be insufficient for fully dissolving the fission products in the glass matrix. In addition Joule heated melters suffer from equipment corrosion, produce a secondary waste, and are susceptible to hazardous/radioactive volatile component losses.

Synroc is expected to provide a cost effective, reliable, and durable waste form. These fundamental and significant benefits are the result of the Synroc formulation method - in that the $\mathrm{Cs} / \mathrm{Sr}$ can be placed in a natural analog crystalline/mineral matrix empirically proven to be nearly insoluble over long time periods [26,34]. Such formulations will decouple the waste form from the waste form disposal environment since there is no alpha decay and no corresponding crystalline waste form decay damage over the relatively short half lives of the Cs and Sr.[26,33] This decoupling furthermore greatly simplifies, and therefore increases the accuracy, of any models required to predict the Cs and $\mathrm{Sr}$ release rates over long time periods in the proposed disposal location. Steam reforming has yet to demonstrate it can produce a $\mathrm{Cs} / \mathrm{Sr}$ waste form of equivalent durability, so as to provide the same level of waste form/disposal site decoupling.[28,29,30]

The use of Synroc as an alternative for the immobilization of the Cs/Sr strip product must continually be evaluated. In particular, optimization of the correct Synroc assemblage matrix for the various $\mathrm{Cs} / \mathrm{Sr}$ feeds would need to be conducted. Some preliminary tests are being conducted by ANSTO (at their expense) this fiscal year to indicate further feasibility of the Synroc waste form for the $\mathrm{Cs} / \mathrm{Sr}$ streams. The results from this testing can then be compared to the tests currently being conducted with a steam reforming approach to $\mathrm{Cs} / \mathrm{Sr}$ immobilization. At this point, a more detailed comparison of fabrication ease, flexibility, chemical durability (leach rate), and costs between the two technologies can be completed to decide between steam reforming and Synroc immobilization. 


\section{REFERENCES}

1. Richard Boardman, Julia Tripp, Jack Law, and Troy Garn, "Review of Cs/Sr Solidification Processes and Engineered Product Storage Forms for FY-05 Experimental Testing at the INL," INL/EXT-05-05-00155, March 2005.

2. Julia Tripp, Richard Boardman, Troy Garn, and Jack Law, "FY-05 Research on Solidification of the Cesium and Strontium Separations Product from Advanced Aqueous Reprocessing of Spent Nuclear Fuel," INL/EXT-05-00766, September 2005.

3. Julia Tripp, Richard Boardman, Troy Garn, and Jack Law, "FY-06 Test Plan for Research on Solidification of the Cesium and Strontium Separations Product from Advanced Aqueous Reprocessing of Spent Nuclear Fuel," INL/EXT-05-01029, December 2006.

4. Uranium Information Center web site (http://www.uic.com.au), Australia, Nuclear Issues Briefing Paper 21, June 2005.

5. M. L. Carter, E. R. Vance, D. R. G Mitchell, J. V. Hanna, Z. Zhang, and E. Loi, "Fabrication, characterization, and leach testing of hollandite, $(\mathrm{Ba}, \mathrm{Cs})(\mathrm{Al}, \mathrm{Ti})_{2} \mathrm{Ti}_{6} \mathrm{O}_{16}$, " Journal of Materials Research, Vol. 17 (No. 10): pp. 25782589, October 2002.

6. Virginie Aubin, Daniel Caurant, Didier Gourier, Noël Baffier, Thierry Advocat, Florence Bart, Gilles Leturcq, and Jean M. Costantini, "Synthesis, Characterization and Study of the Radiation Effects on Hollandite Ceramics Developed for Cesium Immobilization," Scientific Basis for Nuclear Waste Management XXVII, eds. Virginia M. Oversby and L. O. Werme (Materials Research Society Symposium Proceedings), Vol. 807, pp 315- 320, 2004.

7. K. R. Whittle, S. E. Ashbrook, S.A.T. Redfern, G. R. Lumpkin, J. P. Attfield, M. Dove, and I. Farnan, "Structural Studies of Hollandite-Based Radioactive Waste Forms," Scientific Basis for Nuclear Waste Management XXVII, eds. Virginia M. Oversby and L. O. Werme (Materials Research Society Symposium Proceedings), Vol. 807, pp 339-344, 2004.

8. V. Aubin, D. Caurant, D. Gourier, N. Baffier, S. Esnouf, and T. Advocat, "Radiation Effects on Hollandite Ceramics developed for Radioactive Cesium Immobilization," Materials Research Society Symposium Proceedings, Vol. 792, pp. 61-67, 2004.

9. E. R. Vance, "Synroc Ceramics for Nuclear Waste Immobilization," Journal of Australasian Ceramic Society, Volume 38, No. 1, pp. 48-52, 2002.

10. B. D. Begg, R. A. Day, S. Moricca, M. W. A. Steward, and E. R. Vance, "LowRisk Waste Form to Lock up High-Level Nuclear Waste,' WM'05 Conference, February 27-March 3, 2005, Tucson, AZ.

11. J. M. McHale, N. V. Coppa, "Instantaneous Formation of Synroc-B Phases at Ambient Pressure," Scientific Basis for Nuclear Waste Management XIX, eds. William M. Murphy and Dieter A. Knecht (Materials Research Society Symposium Proceedings), Vol. 412, pp 297-303, 1996. 
12. K. P. Hart, E. R. Vance, R. A. Day, B. D. Begg, and P. J. Angel, "Immobilization of Separated Tc and Cs/Sr in Synroc," Scientific Basis for Nuclear Waste Management XIX, eds. William M. Murphy and Dieter A. Knecht (Materials Research Society Symposium Proceedings), Vol. 412, pp 281-287, 1996.

13. W. E. Lee, M. I.Ojovan, M. C. Stennett, and N. C. Hyatt, "Immobilisation of radioactive waste in glasses, glass composite materials and ceramics," Advances in Applied Ceramics, Vol 105, No. 1, 2006.

14. I. A. Sobolev, S. V. Stefanovsky, B. I. Omelianenko, S. V. Ioudintsev, E. R. Vance, and A. Jostsons, "Comparative Study of Synroc-C Ceramics Produced by Hot-Pressing and Inductive Melting," Scientific Basis for Nuclear Waste Management XX, eds. Walter J. Gray and Ines R. Triay (Materials Research Society Symposium Proceedings), Vol. 465, pp 371-378, 1997.

15. A. V. Kudrin, B. S. Nikonov, and S. V. Stefanovsky, "Chemical Durability Study of Synroc-C Ceramics Produced by Through-Melting Method," Scientific Basis for Nuclear Waste Management XX, eds. Walter J. Gray and Ines R. Triay (Materials Research Society Symposium Proceedings), Vol. 465, pp 417-423, 1997.

16. M. L. Carter, E. R. Vance, G. R. Lumpkin, and G. R. Loi, “Aqueous Dissolution of Rb-Bearing Hollandite and Synroc-C at $90^{\circ} \mathrm{C}$," Materials Research Society Symposium Proceedings, Vol. 663, pp. 381-388, 2001.

17. M. L. Carter, E. R. Vance, and H. Li, "Hollandite-rich Ceramic Melts for the Immobilization of Cs," Scientific Basis for Nuclear Waste Management XXVII, eds. Virginia M. Oversby and L. O. Werme (Materials Research Society Symposium Proceedings), Vol. 807, pp 249-254, 2004.

18. M. L. Carter, E. R. Vance, and H. Li, "Hollandite-Rich Titanate Ceramics Prepared by Melting in Air," Ceramic Transactions, Environmental Issues and Waste Management Technologies IX, pp 21-30, 2004.

19. F. Bart, G. Leturcq, and H. Rabiller, "Iron-substituted Barium Hollandite Ceramics for Cesium Immobilization," Ceramic Transactions, Environmental Issues and Waste Management Technologies IX, pp 11-20, 2004.

20. F. Bart, G. Leturcq, and H. Rabiller, "Chemical Durability of Iron-substituted Hollandite Ceramics for Cesium Immobilization," Ceramic Transactions, Environmental Issues and Waste Management Technologies X, pp 217-224, 2005.

21. S. A. Petrov, L. F. Grigor'eva, O. Yu. Sinel'shchikova, T. Yu. Sinel'shchikova, and V. V. Gusarov, "Synthesis and Study of Isomorphous Miscibility Limits of Crystalline Phases with a Hollandite-Type Tunnel Structure in the $\mathrm{Cs}_{2} \mathrm{O}(\mathrm{MeO})$ $\mathrm{Al}_{2} \mathrm{O}_{3}-\mathrm{TiO}_{2}(\mathrm{Me}=\mathrm{Ba}, \mathrm{Sr})$ Systems," Glass Physics and Chemistry, Vol. 29, No. 3, pp. 316-321, 2003.

22. C. C. Herman, D. F. Bickford, D. K. Peeler, D. Gombert, J. Richardson, R. Goles, J. D. Vienna, A. Aloy, and S. Stefanovsky, "Cold Crucible Induction-Heated Melter Test Results with Surrogate DOE High-Level Wastes," WSRC-MS-200300261.

23. Richard D. Boardman, Bradley J. Ward, "Final Test Report: Synroc Precursor Production Trials in a Fluidised Bed," INEEL/EXT-04-01624, June 2004, limited distribution. 
24. J. L. Tripp, T. G. Garn, R. D. Boardman, and J. D. Law, "Steam Reforming Solidification of Cesium and Strontium Separations Product from Advanced Aqueous Processing of Spent Nuclear Fuel," Waste Management 06 Conference Proceedings, Tucson, AZ.

25. M. L. Carter, "Hollandite -Rich Ceramics for the Immobilization of Cs," Environmental Issues and Waste Management Technologies in the Ceramic and Nuclear Industries XI, eds. Herman, Marra, Spearing, Vance, Vienna(Proceedings of the $107^{\text {th }}$ Annual Meeting of the American Ceramic Society, Baltimore Maryland, USA (2005)), Ceramic Transactions, Volume 176. Published by The American Ceramic Society-2006.

26. R. Devanathan, W. J. Weber, "Computational and Experimental Studies of the Radiation Response of $\mathrm{Gd}_{2} \mathrm{Ti}_{2} \mathrm{O}_{7}$ Pyrochlore," Environmental Issues and Waste Management Technologies in the Ceramic and Nuclear Industries XI, eds. Herman, Marra, Spearing, Vance, Vienna- (Proceedings of the $107^{\text {th }}$ Annual Meeting of the American Ceramic Society, Baltimore Maryland, USA (2005)), Ceramic Transactions, Volume 176. Published by The American Ceramic Society-2006.

27. D. S. Perera, E. R. Vance, A. Zaynab, J. Davis, C. L. Nicholson, "Immobilization of Cs And Sr in Geopolymers with Si/Al Molar Ratio of 2," Environmental Issues and Waste Management Technologies in the Ceramic and Nuclear Industries XI, eds. Herman, Marra, Spearing, Vance, Vienna- (Proceedings of the $107^{\text {th }}$ Annual Meeting of the American Ceramic Society, Baltimore Maryland, USA (2005)), Ceramic Transactions, Volume 176. Published by The American Ceramic Society-2006.

28. M. Cowan, B. J. Mason, K. Ryan, D. Schmoker, "Steam Reforming Technology for Denitration and Immobilization of DOE Tank Wastes," Environmental Issues and Waste Management Technologies in the Ceramic and Nuclear Industries XI, eds. Herman, Marra, Spearing, Vance, Vienna- (Proceedings of the $107^{\text {th }}$ Annual Meeting of the American Ceramic Society, Baltimore Maryland, USA (2005)), Ceramic Transactions, Volume 176. Published by The American Ceramic Society-2006.

29. T. Lorier, C. Jantzen, J. Marra, J. Pareiz, "Feed Reactivity Study for Fluidized Bed Steam Reformer (FBSR) Processing," Environmental Issues and Waste Management Technologies in the Ceramic and Nuclear Industries XI, eds. Herman, Marra, Spearing, Vance, Vienna- (Proceedings of the $107^{\text {th }}$ Annual Meeting of the American Ceramic Society, Baltimore Maryland, USA (2005)), Ceramic Transactions, Volume 176. Published by The American Ceramic Society-2006.

30. C. Jantzen, J. Pareizs, T. Lorier, J. C. Mara, "Durability Testing of Fluidized Bed Steam Reforming (FBSR) Products," Environmental Issues and Waste Management Technologies in the Ceramic and Nuclear Industries XI, eds. Herman, Marra, Spearing, Vance, Vienna- (Proceedings of the $107^{\text {th }}$ Annual Meeting of the American Ceramic Society, Baltimore Maryland, USA (2005)), Ceramic Transactions, Volume 176. Published by The American Ceramic Society-2006. 
31. C. Jantzen, N. E. Bibler, "The Product Consistency Test (ASTM C1285) for Waste Form Durability Testing," Environmental Issues and Waste Management Technologies in the Ceramic and Nuclear Industries XI, eds. Herman, Marra, Spearing, Vance, Vienna-(Proceedings of the $107^{\text {th }}$ Annual Meeting of the American Ceramic Society, Baltimore Maryland, USA (2005)), Ceramic Transactions, Volume 176. Published by The American Ceramic Society-2006.

32. A. P. Kobelev, S. V. Stefanovsky, O. A. Knyazev, T. N. Laschenova, J. C. Marra, E. W. Holtzscheiter, C. C. Herman, "Induction Heated Cold Crucible Melter Testing with Troublesome High Level Waste Components," Environmental Issues and Waste Management Technologies in the Ceramic and Nuclear Industries XI, eds. Herman, Marra, Spearing, Vance, Vienna- (Proceedings of the $107^{\text {th }}$ Annual Meeting of the American Ceramic Society, Baltimore Maryland, USA (2005)), Ceramic Transactions, Volume 176. Published by The American Ceramic Society-2006.

33. W. J. Weber, Ewing, Diaz de la Rubia, Hobbs, Matzke, Kinoshita, Motta, Vance, Natasi, Salje, Zinkle, "Radiation effects in crystalline ceramics for the immobilization of high -level nuclear waste and plutonium," Commentaries and Reviews in the Journal of Materials Research, Vol. 13, No.6, Jun 1998. Pp.14341484.

34. A. E. Ring wood, S. E. Kesson, K. E. Reeve, D. M. Levins, E. J. Ramm, Radioactive Waste Forms for the Future, eds. Werner, Lutze and Ewing, North Holland Physics Publishing, Chapter 4-SYNROC, pp. 233-334, 1988. 